
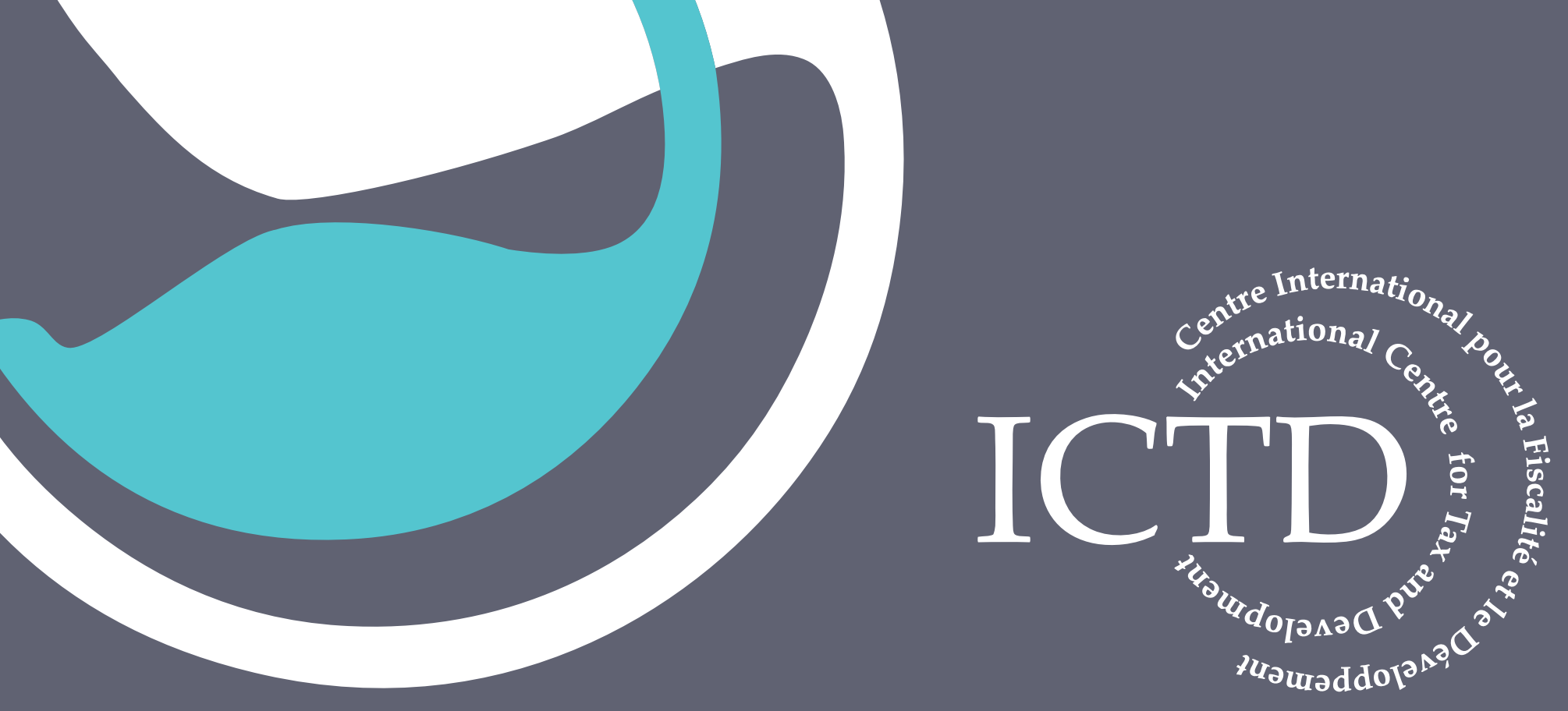

Working Paper 40

\title{
Irimitations of the BEPS Reforms: Looking Beyond Corporate Taxation for Revenue Gains
}

Michael C. Durst

September 2015 
ICTD Working Paper 40

\section{Limitations of the BEPS Reforms: Looking Beyond Corporate Taxation for Revenue Gains}

Michael C. Durst

September 2015

A version of this paper has previously been published by Bloomberg BNA, Inc., which reserves all rights. Reprinted by permission. 
Limitations of the BEPS Reforms: Looking Beyond Corporate Taxation for Revenue Gains Michael C. Durst

ICTD Working Paper 40

First published by the Institute of Development Studies in September 2015 with permission by Bloomberg BNA Inc.

(C) Bloomberg BNA, Inc.

ISBN: 978-1-78118-252-9

This publication is copyright, but may be reproduced by any method without fee for teaching or nonprofit purposes, but not for resale. Formal permission is required for all such uses, but normally will be granted immediately. For copying in any other circumstances, or for reuse in other publications, or for translation or adaptation, prior written permission must be obtained from the publisher and a fee may be payable.

Available from:

The International Centre for Tax and Development

at the Institute of Development Studies,

Brighton BN1 9RE, UK

Tel: +44 (0) 1273606261 Fax: +44 (0) 1273621202

E-mail: info@ictd.ac.uk

Web: www.ictd/en/publications

IDS is a charitable company limited by guarantee and registered in England (No. 877338) 


\title{
Limitations of the BEPS Reforms: Looking Beyond Corporate Taxation for Revenue Gains
}

\author{
Michael C. Durst
}

\section{Summary}

This paper argues that global corporate tax policies have long been dominated by a political consensus among governments of countries at all levels of economic development, to the effect that forces of tax competition render taxation of the cross-border income of multinational companies both infeasible and unwise. Current tax laws around the world, which permit widespread tax avoidance through shifting corporate profits to tax havens, reflect the implementation of this political consensus. The global political consensus against effective corporate tax rules seems likely to survive the current efforts of the OECD, in its studies of base erosion and profit shifting (BEPS), to devise legislation that would revitalise corporate income tax. Countries around the world, therefore, are unlikely to implement more than symbolic and minimally incremental BEPS reforms.

This paper warns that the current high level of attention being paid to BEPS in the media and by international organisations might lead developing country governments to expect unrealistic returns from efforts to implement BEPS-related reforms. The paper therefore advises governments of developing countries to be selective in allocating resources to implementation of BEPS reforms, generally focusing only on those reforms that will clearly generate increased revenue in light of the very limited administrative resources typically available to developing country revenue agencies. In general, developing countries will be well advised to devote the bulk of their enforcement resources to the development of fiscal instruments that do not encounter the political obstacles facing taxation of cross-border corporate income. These include excise and general consumption taxation, income taxation of large and medium-sized domestic businesses, natural resource royalties (as opposed to income-based taxes on mineral producers), real property taxation and payroll taxation.

Keywords: developing country taxation; base erosion and profit shifting; transfer pricing.

Michael C. Durst is a long-time US tax practitioner, an author on international taxation and developing countries, a former government official and law professor, and an ICTD researcher. 


\section{Contents}

Summary 3

Acknowledgements $\quad 5$

Abbreviations $\quad 5$

Introduction 6

$1 \quad$ The political forces of tax competition $\quad 7$

2 The vulnerability that is built into corporate income tax 9

2.1 In general 9

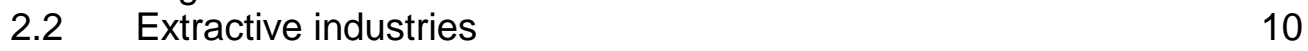

$3 \quad$ The likely outcome of the BEPS project 11

3.1 Current political posture of BEPS efforts 11

3.2 Likelihood of transfer pricing reforms 12

3.3 Likelihood of effective CFC reforms 13

$4 \quad$ Post-BEPS directions in developing country tax policy 13

4.1 Overall policy priorities 13

$\begin{array}{lll}4.2 & \text { Natural resource taxation } & 14\end{array}$

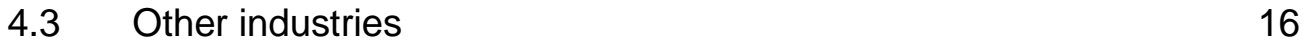

$\begin{array}{lll}5 & \text { Conclusion } & 18\end{array}$

$\begin{array}{ll}\text { References } & 19\end{array}$ 


\section{Acknowledgements}

The author is grateful for comments that were provided by peer reviewers for ICTD.

\section{Acronyms}

$\begin{array}{ll}\text { BEPS } & \text { Base Erosion and Profit Shifting } \\ \text { CFC } & \text { Controlled Foreign Corporation } \\ \text { ICTD } & \text { International Centre for Tax and Development } \\ \text { NGO } & \text { Non-Governmental Organisation } \\ \text { OECD } & \text { Organisation for Economic Co-operation and Development }\end{array}$




\section{Introduction}

Developing countries often are said to have greater need for revenue from corporate income tax than the wealthier countries of the world. Because of widespread 'informality' in their economies, including heavy reliance on cash as a medium of payment, developing countries face serious limitations on their ability to raise revenue from domestic sources, including personal income and consumption taxes. In addition, the economies of developing countries often depend heavily on income from inbound investment in a wide variety of industries. For these reasons, those working in the Organisation for Economic Co-operation and Development (OECD) and other forums to recommend legislative and administrative reforms to curtail base erosion and profit shifting (BEPS) often express hope that their work will be of particular benefit to the world's developing economies. ${ }^{1}$

The OECD's BEPS project is now approaching its conclusion. The OECD has already released an impressive series of discussion drafts that indicate the direction the final BEPS recommendations are likely to take, and the OECD's likely recommendations already have been debated among lawmakers and other tax policymakers around the world. The BEPS materials released to date by the OECD are insightful and well-crafted, and despite virtually certain political opposition it seems likely that countries around the world will adopt at least some elements of the OECD's envisioned program.

But it is also clear that the legislative and regulatory reforms that result from the BEPS recommendations will result at best in only the partial curtailment of profit shifting. The strong political and economic forces - forces of tax competition - that brought about the erosion of the world's corporate tax base over time remain highly influential, and they may be stronger than ever. Moreover, even apart from the problem of tax competition, the basic structure of corporate income tax makes it peculiarly vulnerable to revenue erosion even through relatively small amounts of profit shifting.

The combination of the continued political pressures of tax competition, and the inherent structural vulnerability of corporate income tax, make it very unlikely that the current BEPS reform efforts will result in a corporate income tax that can meet developing countries' needs for public revenue. There is, further, a danger for developing countries that the BEPS project will generate unrealistically heightened expectations for enhancement of revenue yields from corporate tax. By relying too heavily on expectations of corporate tax reform, countries might give insufficient attention to other fiscal instruments that may offer more realistic promise of generating additional revenue.

This article argues that while developing countries should remain closely engaged with the BEPS reform efforts of the OECD and other international organisations, developing countries should also direct substantial portions of their tax reform efforts toward development of important revenue sources other than corporate income tax. In particular, this article:

(i) describes the political forces that over the years have resulted in the widespread impairment of corporate income tax, in countries at all levels of economic development, through base erosion and profit shifting;

(ii) illustrates an unavoidable structural anomaly of corporate income tax in the international setting that renders it inherently resistant to effective reform;

(iii) suggests that while developing countries generally should seek to improve their corporate income tax laws in response to the recommendations that are likely to arise from the BEPS process, countries should also devote serious attention to further 
development of alternative revenue sources, which may well offer greater prospects for substantial revenue gains, even if BEPS reforms can be successfully implemented.

\section{The political forces of tax competition}

The OECD's efforts to curtail base erosion and profit shifting began when non-governmental organisations (NGOs) and investigative journalists working for mainstream media outlets around the world, explained the phenomenon of profit shifting by multinational business groups in language that could be understood by members of the general public. ${ }^{2}$ The revelations by NGOs and the media led to forceful demands by political leaders in some countries to remedy the erosion of corporate tax bases. These political demands led in turn to the initiation of the current BEPS efforts in the OECD.

The reports of widespread profit shifting that led to the OECD's BEPS effort may have been surprising to the general public, but they could not have been surprising to the executives of multinational companies, to international tax lawyers and accountants, and to those politicians around the world who have been actively engaged in the writing of tax laws. The legal mechanisms that support the practice of profit shifting have been present for many decades. Lawyers for multinational companies devised them and put them in place in the days immediately following World War II, largely in response to the rapid growth of global trade in high-margin products that arose from the invention of the post-War 'wonder drugs'. ${ }^{3}$ Large-scale profit shifting quickly became universal within the pharmaceutical industry, and the practice grew further with the expansion of multinational enterprise that has accompanied the global technological revolution that began in the 1980s.

The idea that lawyers succeeded in embedding in corporate tax laws around the world was the notion that companies within the same multinational group could, by making contracts with one another, dictate to tax authorities where the group's income should be treated as being earned. At first companies applied this approach to contracts that assigned ownership in patents and other intangible rights to subsidiaries established by the groups in low- or zero-tax countries. Over time, as acceptance of the use of intragroup contracts to shift income grew, taxpayers expanded their use of related-party contracts to shift profits for tax purposes, using them, for example, to establish on paper loans from low- and zero-tax subsidiaries to operating companies within the group, thereby justifying large payments of deductible interest from countries in which group members conduct their business activities; and also using contracts to assign specified business risks to low- or zero-tax subsidiaries, thereby justifying payments of numerous kinds in return for the risk-bearing that ostensibly is taking place. ${ }^{4}$

From the standpoint of normal legal principles, the idea that tax consequences might be determined by contracts between identically-owned corporations is on its face implausible. Indeed, in other areas of the tax law, no-one would seriously entertain the notion that contracts between parties with non-adverse economic interests would be given weight in determining tax consequences. Instead, logic would hold that instead of contracts between parties with identical economic interests, the observable facts of the dealings among related companies - particularly, what the different companies actually do, and where they do it would govern the apportionment of income among the companies for tax purposes.

See, for example, ActionAid (2012); Christian Aid (2009); Drucker (2011); Duhigg and Kocieniewski (2012) .

Useful historical discussions can be found in Avi-Yonah (1997); Avi-Yonah and Clausing (2007); Durst and Culbertson (2003); Langbein (1986); Wells and Lowell (2012).

Comprehensive discussions of base erosion and profit shifting, in their contemporary forms, can be found in Kleingard (2011a, 2011b) and US Congress (2010). 
Consider, for example, the common occurrence in domestic business taxation, in which a seller sells to a buyer property consisting of both depreciable and non-depreciable assets. The seller in this circumstance often does not care how the purchase price should be apportioned between the depreciable and non-depreciable assets, whereas the buyer, seeking the highest level of future depreciation deductions, may prefer that as large a portion as possible of the depreciable assets be attributed to the depreciable property. The parties might 'agree' by contract to an apportionment that assigns a large portion of the total value to the depreciable property, but the law would not bind the revenue agency to the parties' agreement. Instead, the law will require the buyer to present facts establishing the value of the depreciable property, without regard to the self-serving valuation that might have been stated in a collusive contract. The law sensibly requires that the actual facts, not how the parties might characterise the facts in a self-serving legal agreement, governs the tax consequences of a transaction. But tax laws around the world - 'transfer pricing' laws, which govern the apportionment of income among members of commonly controlled corporate groups - have consistently given substantial deference to the apportionment of income that the parents of multinational groups cause their subsidiaries to write into contracts between themselves.

Transfer pricing laws typically allow tax authorities some latitude to challenge the bona fides of these contracts if the relationships between companies specified in the contracts depart manifestly from the parties' actual dealings. But the test for overriding contracts generally is highly subjective, and tax authorities' theoretical ability to challenge the bona fides of taxpayer contracts has not in practice resulted in meaningful constraints on profit shifting. The result has been the tremendous expansion of profit shifting that has given rise to today's BEPS process.

This history raises the question of why governments around the world, which suffer large losses of national revenue from profit shifting through the use of related-party contracts, have tolerated the practice for many decades. The reason lies in the fact that despite governments' tendency to retain corporate taxes on their books, and to give verbal support to reform studies like that now being conducted by the OECD, all the parties that are most politically influential in tax policymaking - multinational corporations themselves, and governments of both developing and wealthy countries around the world - perceive benefit in defeating the operation of corporate tax as it applies to income from cross-border operations. $^{5}$

The interest in tax avoidance of multinational corporations themselves is not hard to understand - their shareholders would prefer as a matter of course to pay as little tax as possible. For governmental policymakers around the world, the interest in hobbling corporate income tax in the international setting arises from the influence of two different kinds of tax competition. Governmental actors in the wealthier capital-exporting countries of the world, which tend to be home to the world's multinational businesses, face strong political pressure to protect the competitive positions of their home-based multinationals. This has translated to a reluctance on the part of many wealthy countries to take measures that would constrain their multinationals from shifting profits from the countries in which they operate around the world. ${ }^{6}$ In the world's developing countries, tax policymakers face competitive pressure of a different kind: policymakers have tended to be averse to any legal measures that might be seen as discouraging inbound investment. As a result, developing country governments as well as governments of wealthier countries have tended to resist legal reforms that might prevent profit shifting.

For an influential and early analysis of this phenomenon, see Avi-Yonah (2000).

This reluctance has taken the form, in part, of the willingness of governments to permit their controlled foreign corporation (CFC) rules, which are designed to discourage multinationals from shifting income from countries in which they conduct business, to weaken. For discussion of this topic, see, e.g., Durst (2014a). 
In short, for many years there has been agreement among multinational companies and policymakers around the world to allow corporate tax to atrophy, as it applies to income from cross-border operations, through contractually-based profit shifting. ${ }^{7}$ Of course, the agreement is rarely made explicit. Corporate income tax has substantial ideological appeal in many quarters, particularly among some who perceive the tax as ensuring that multinational companies are making adequate contributions to public welfare around the world. In addition, some perceive corporate income tax as playing a role in mitigating inequalities of wealth around the world. There is no point in needlessly confronting the political constituencies that hold these views. And, by and large, there has been no need for those supporting current practices of profit shifting to defend their positions explicitly. The inherent complexity of corporate tax laws has, as a general matter, sufficed to shield the flowering of tax avoidance through the use of intragroup contracts from significant public scrutiny.

The media and NGO reports that gave rise to the BEPS inquiry seem have succeeded, at least temporarily, in piercing the veil of complexity that has for decades shielded the international corporate tax system from public scrutiny. But the recent public exposure has done nothing to diminish the imperatives of tax competition that have for decades induced governments around the world to permit profit shifting on a very large scale.

Possibly, public interest in international corporate tax reform will persist with an intensity that can override the political tendency toward tax competition, and produce reforms that will substantially curtail base erosion and profit shifting. Historical experience, however, suggests that developing countries should not rely heavily on a result of that kind. It seems likely instead that popular political interest in international corporate taxation will fade over time in favour of other emergent public issues, if public interest has not begun to fade already. Moreover, there are already ample signs that the political forces of tax competition will succeed in weakening proposed BEPS reforms, in part through including in the BEPS reports stern-sounding and verbally complex changes to international transfer pricing guidelines that purport to constrain income-shifting through contracts, but in fact give governments few if any workable new standards by which to address the problem. More will be said below about the emerging results of the BEPS process. First, however, it may be useful to describe an intrinsic, structural limitation on corporate income taxation that would impair the revenueraising capacity of the tax in the international setting, even if there were more political will to implement the tax effectively.

\section{The vulnerability that is built into corporate income tax}

\subsection{In general}

It is universally recognised that the application of corporate income tax to multinational businesses depends heavily on the tax administration's ability to enforce the fair market valuation (arm's-length pricing) of goods and services that are sold between related parties. Consider, for example, a member of a multinational group that purchases brand name beverages from its related foreign supplier, and resells them to unrelated buyers in a particular country. For income tax purposes, the tax administration has the task of ensuring the distributor does not pay its related supplier more than fair market value for the beverages it imports, as that would squeeze the distributor's taxable margin and will lead to partial

A prominent UK tax practitioner has observed, 'I don't think that over the last 20 years or so, one can say that governments have driven corporate tax policy; it's the large companies that have driven large corporate tax policy' (Qassim 2015) 
avoidance of local income tax. Similarly, the tax administration needs to ensure that the distributor doesn't inflate its expenses and thus reduce its taxable income by, for example, paying trademark royalties to its supplier at higher than a fair-market rate. The need to prevent misvaluations of this kind, in transactions between members of multinational groups in every industry around the world, is well-known to taxpayers, tax practitioners and tax authorities.

What is not always understood, however, is that: (i) even small misvaluations in product prices can lead to very large understatements of a taxpayer's tax liability; and (ii) corporate income tax is much more vulnerable to avoidance through misvaluations than alternative kinds of taxes that governments might use to raise revenue from multinational businesses operating in their countries, including excise taxes and ad valorem royalties on extracted natural resources.

Consider first the situation of, say, a beverage importer like that described above. ${ }^{8}$ Assume that in a given year the importer sells products to unrelated parties in its country of operation worth $\$ 100$ million. Assume as well that the proper fair market value, at wholesale, of the product that the importer has purchased from its related supplier is $\$ 80$ million, and that the importer has incurred operating expenses that are properly valued at $\$ 10$ million. The importer's proper taxable income is therefore $\$ 100$ million minus $\$ 80$ million minus $\$ 10$ million, or $\$ 10$ million. Assume further that the country in which the importer operates imposes a corporate income tax at a rate of 30 per cent. The importer's proper tax liability therefore is $\$ 3$ million. Assume now, however, that the importer overstates the value of the beverages that it imports by 10 per cent - a deviation that will be difficult at best for tax authorities to detect. The importer will then report a taxable income not of $\$ 10$ million but of only $\$ 2$ million, and its income tax liability will be reduced from the proper amount of $\$ 3$ million to only $\$ 600,000$. A 10 per cent misvaluation of the imported product therefore has given rise to an 80 per cent shortfall in tax revenue.

Consider now the significance of the misvaluation if, instead of trying to impose a tax on the importer's income, the government imposes a 3 per cent excise tax on the sale of beverages of the kind the importer sells. Given the importer's sales during the year of $\$ 100$ million, the excise tax should raise $\$ 3$ million in revenue - the same as would be raised by the corporate tax considered above if it could be administered successfully. Now, the excise tax will not be entirely immune from avoidance: by, for example, misrepresenting sales records, the importer, or perhaps resellers who purchase from the importer, might succeed in understating their sales volume by, say, 10 per cent. The result would be that revenue from the excise tax also would be reduced by 10 per cent, from $\$ 3$ million to $\$ 2.7$ million. This loss would be regrettable - but far less serious as a fiscal matter than the 80 per cent decline in tax revenues brought about by a 10 per cent misevaluation of imported product under corporate income tax. Under the excise tax, a 10 per cent misevaluation of product sold reduces the revenue yield from the tax by only 10 per cent. The excise tax is far less vulnerable to avoidance by misevaluation than an equivalent corporate income tax.

\subsection{Extractive industries}

Natural resources are central to the economies of many developing countries, so it is important to recognise how the special vulnerability of income taxation to valuation misstatements is expressed in the taxation of extractive industries. Consider, for example, a mining company that extracts ore within a country under a government concession agreement. In a particular year, the company extracts and sells ore with a true fair market value of $\$ 100$ million. The company incurs bona fide expenses of $\$ 90$ million, so that its properly measured taxable income is $\$ 10$ million; and an income tax of 30 per cent on the

A similar example can be found in Durst (2014b). 
mining company should yield the government revenue of $\$ 3$ million. If, however, the company understates its sales revenue by 5 per cent, the company will report revenue of $\$ 95$ million minus $\$ 90$ million, or only $\$ 5$ million. The government's tax revenue will fall from $\$ 3$ million to $\$ 1.5$ million. A 5 per cent understatement of value by the taxpayer will have reduced the government's revenue by 50 per cent.

Now consider the situation in which instead of subjecting the mining company to an income tax, the government imposes a 3 per cent royalty on the value of extracted product. Theoretically, based on the true valuation of the company's product at $\$ 100$ million, this royalty would yield the government $\$ 3$ million, the same amount that would be raised under the income tax if it could be successfully applied. Under the royalty the company will, just as under an income tax, have incentive to undervalue its product. If in response to this incentive the company undervalues its product by 5 per cent, the government's revenue in that situation will go down - but it will go down only by 5 per cent, from $\$ 3$ million to $\$ 2.85$ million - much less than the 50 per cent loss of revenue occasioned by the same misevaluation under the income tax.

In practice, the possibility that mining companies will undervalue their product for tax purposes is very large. It is common for natural resource companies operating in developing countries to sell their raw product, like ore, not directly to third parties but instead to related purchasing companies established in low- or zero-tax countries. The companies therefore have not only the tax motivation, but ample opportunity, to sell their product at lower than fair market value. And given the difficulty of determining the value of mineral products, which can depend heavily on the quality of a particular mineral deposit and the distance of the mine or well from available markets, significant undervaluations are virtually certain to occur. The consequences of these undervaluations are much more serious under income-based taxes than under royalties and similar ad valorem levies.

\section{The likely outcome of the BEPS project}

\subsection{Current political posture of BEPS efforts}

In light of the very high sensitivity of corporate income tax to even small amounts of profit shifting through transfer mispricing, only two kinds of legal reform would appear to be sufficiently fundamental to curtail it to a fiscally substantial extent. First, countries could revise transfer pricing rules so as to disregard the claimed effects of contracts made between members of commonly controlled groups, and instead look to the actual geographic locations of the group members' business activities - for example, where their employees are stationed and where their customers are located - in determining how income should be apportioned between group members. Alternatively, the major capital exporting countries of the world could agree to adopt effective systems of CFC rules ${ }^{9}$ and thereby remove from multinational groups the financial incentive for income shifting.

It is already clear, however, even with the BEPS process not yet complete, that neither of these comprehensive remedies for profit shifting is within the realm of political acceptability to any OECD country. Instead, it seems likely that reforms will be limited to incremental changes to laws and administrative practices that may pose some worthwhile benefits to governments in protecting their revenues, but will continue to leave open opportunities for profit shifting to multinationals on a large scale.

See note 6 above. 


\subsection{Likelihood of transfer pricing reforms}

In the area of transfer pricing, key participants in the BEPS process have from the start ruled out eliminating reliance on contracts in apportioning group income, in favour of the observed geographic distribution of a group's income-producing activities. ${ }^{10}$ That course of action, which would have resulted in what might fairly be described as a 'formulary' approach to apportionment, has long been politically anathema. Opponents of the approach argue that it would raise serious and unsolvable technical problems; others (including this author) have believed that the technical problems have been exaggerated, and that the true source of opposition to the formulary approach has been not technical concerns but instead political aversion arising from pressures of tax competition. ${ }^{11}$ Whichever view on this question might be correct, however, as a practical matter there is no possibility that the BEPS process will result in the adoption of transfer pricing rules that disregard the effects of related-party contracts and look only to evidence of where a company's physical activities take place. Instead, changes to transfer pricing rules arising from BEPS are likely to consist of: (i) verbal adjustments to the standards under which tax authorities will be permitted to disregard contractual terms that seem manifestly inconsistent with taxpayers' actual business practices; and (ii) changes to the volume and nature of the information (contemporaneous documentation, in the language of transfer pricing practice) that taxpayers are required to make available to tax authorities to assist the authorities in transfer pricing examinations.

The adjusted standards for overriding contracts seem certain to remain highly subjective, as any attempts to quantify the standards will run foul of the widespread aversion to the use of formulas. It is possible that adjustments to subjective standards, if skillfully designed, will result in some meaningful increase in the practical reach of tax enforcement - but copious experience to date has shown that tax authorities face inherent difficulty in convincing courts or other fact-finders of the validity of subjective findings. Tax laws, of all laws, seem suited to bright-line rules rather than subjective verbal standards; and the probability is high that the practical effects, if any, of modified verbiage in transfer pricing guidelines will be incremental rather than transformative.

Similarly, the recommendations for enhanced documentation requirements that arise from BEPS may lead to some advances in enforceability, but any effects will be relatively limited. One particular innovation, a requirement that taxpayers provide examiners with country-bycountry breakdowns of both their tax liabilities and the locations of their physical activities, may have significant effects, as the reporting may help focus examiners' enforcement efforts on those companies that appear to be shifting the highest volumes of profits. Overall, however, requirements that taxpayers give tax authorities enhanced access to information about companies' activities are likely to offer relatively small practical benefits to enforcement.

A key underlying problem of today's transfer pricing laws is that they compel tax authorities to marshal and assess unrealistically large and complex volumes of factual material. The practical problem in enforcement is not too little documentation, but too much. In practice, therefore, the expansion of documentation requirements envisioned by the BEPS process is unlikely to reduce materially the amount of income that multinational groups can successfully shift under arm's-length transfer pricing rules.

\footnotetext{
10 For discussion of this topic, see, e.g., Bell (2015).

11 The author has offered a comparative analysis of current transfer pricing rules with a possible formulary approach in Bloomberg BNA Tax Management Portfolio 6938, 'A Formulary System for Dividing Income Among Tax Jurisdictions'.
} 


\subsection{Likelihood of effective CFC reforms}

The OECD has, since the beginning of the BEPS process, given substantial attention to the possibility of a substantially strengthened network of CFC rules among the world's capitalexporting countries (OECD 2015). A network of CFC rules can be politically feasible, however, only if it is to be enacted and enforced multilaterally by countries that, in the aggregate, are home to all or almost all of the world's large multinationals. If coverage is incomplete, multinationals based in non-enacting countries will continue to derive tax advantages from shifting profits from countries in which they operate, giving those multinationals a competitive advantage in the global marketplace. Enacting countries will then face strong pressure to relax or eliminate their own CFC rules, and the world will end up essentially where it is now - with only spotty coverage of CFC rules around the world, and with the rules of some major economic powers, including the United States and the United Kingdom, essentially ineffective in deterring their multinationals from engaging in profit shifting. ${ }^{12}$

Recently, in response to the BEPS effort, the US Treasury has proposed a version of CFC rules that, if enacted by countries globally, could indeed lead to elimination or substantial curtailment of profit shifting ${ }^{13}$ - but politically the proposal has garnered little if any support within the United States, and there is no realistic chance of its enactment within the foreseeable future. Other countries around the world, including notably the United Kingdom, have shown no inclination to devote energy or political capital to building a global network of CFC rules that could be effective in addressing profit shifting.

\section{Post-BEPS directions in developing country tax policy}

\subsection{Overall policy priorities}

In sum, although reforms generated by BEPS may offer countries some prospect of improved revenue yields from corporate income tax, the BEPS reforms are likely to leave opportunities for multinationals to continue to avoid large volumes of taxes through profit shifting. In view of this likely prospect, developing country governments would be prudent to look for sources in addition to corporate income tax when searching for substantial enhancements in revenue collection.

An important caution is in order: despite the limited nature of the improvements that can be expected from the BEPS process, the revenue enhancements from even incremental BEPS reforms could be of significant value. Developing countries should remain engaged in the BEPS process and should carefully evaluate the extent to which the reforms proposed by the OECD could improve the performance of their corporate tax regimes. Developing countries should, however, be selective in devoting their political and administrative resources to BEPS-based reforms, and they also should preserve some of those resources for the further development of revenue sources other than corporate income tax.

With respect to BEPS reforms, for example, it appears now that the BEPS process may generate recommendations for some relatively simple limitations on the deduction of related-

See the discussion in Durst (2014a).

23 Transfer Pricing Report 1238, 5 February 2015. 
party interest expense. The recommendations will not erect a comprehensive barrier against profit shifting through interest expense, and revenue recovery from the new limitations may be modest for many countries. ${ }^{14}$ Nevertheless, the administrative costs of applying the new limitations probably will be relatively low, and it may well turn out to be sensible for developing country governments to implement them. Similarly, the BEPS process is likely to expand upon the OECD's previous recommendation that countries consider adopting transfer-pricing safe harbours for evaluating whether local manufacturing and distribution affiliates of multinational groups are earning sufficient net operating margins. ${ }^{15}$ The application of transfer pricing safe harbours is likely to provide only limited revenue gains to tax authorities, but the safe harbours should save enforcement costs, and even the limited revenue gains that might be achieved could well be worthwhile.

Developing country governments, however, should probably avoid committing substantial resources toward attempting to implement some other recommendations that are likely to arise from the BEPS process. For example, although developing countries should take advantage of new country-by-country reporting rules, and should participate in new avenues for information exchange among countries, developing countries should otherwise be wary of increasing the amount of information that taxpayers must compile in annual transfer pricing documentation. The primary effect of increased documentation requirements could well be to overloading examiners with peripheral information that will add little to the effectiveness of enforcement efforts. Similarly, although developing countries probably should adopt whatever verbal formulation arises from the BEPS process to articulate when tax authorities should be permitted to disregard the terms of intragroup contracts, developing countries probably should limit their spending on training and enforcement activities based on the new language. The language likely to arise from the BEPS process regarding related-party contracts probably will be too imprecise and subjective to be applied with much practical result even by the best resourced and most experienced of tax administrations.

Overall, therefore, the revenue enhancements made available by BEPS, while potentially significant, will remain limited, and developing country governments will need to look beyond corporate income tax if countries are realistically to increase their revenue from the activities of multinational companies doing business within their boundaries. This will be especially important with respect to those industries: (i) that tend to be especially important to the economies of developing countries; and (ii) that appear to have succeeded to the greatest extent in avoiding income tax liabilities through profit shifting.

For many developing countries, natural resource extraction will be among the highest priority industries to address. For all developing countries, the list of highest priority industries probably should include telecommunications services (including mobile telephone services), the distribution of high-margin consumer products (like branded beverages and foods), and banking and other financial services (including insurance).

\subsection{Natural resource taxation}

In many countries, natural resource producers are subject to a combination of taxes, typically including a royalty of some kind based on the gross value of raw product that is extracted, and some kind of income-based levy on the producer's net profits. The tax on net profits might consist of the regular corporate income tax that is applicable generally in the country, or it may consist of a specialised income-based levy like a resource rent tax. ${ }^{16}$ Economic theory has led many to recommend that countries weight their natural resource levels

For the author's views on this topic, see Durst (2015).

See Mitchell (2013).

Useful background discussions of natural resource taxation, from an economic perspective, include IMF (2012); ICMM (2009); Sunley et al. (2002). 
towards reliance on net income based levies, and away from measurements like royalties that are based on the gross value of extracted products. The reasoning is that income taxes, which unlike royalties and similar levies apply if the producer is successful on a net basis, help mitigate the producer's economic risks. This reasoning is sound in theory, but in practice net income based taxes on natural resource producers are so vulnerable to misvaluation of both product value and intercompany charges, for interest and other expenses, as to be impossible to administer with a reasonable degree of success. ${ }^{17}$

It is common practice among resource producers operating in developing countries to sell their raw product, like ore or raw petroleum, in the first instance to related purchasing companies operating in zero- or low-tax jurisdictions. This provides the producers with opportunities for tax avoidance by under-valuing the raw product that is sold. The undervaluation may be modest - maybe undervaluing the product by only a few percentage points - but as illustrated in the examples above, even a small undervaluation of product can deprive the government of the producing country of very substantial amounts of revenue. Natural resource extractors, moreover, can avoid income tax liabilities through other kinds of profit shifting, notably the use of loans and intercompany service agreements involving related parties in low- or zero-tax countries. Although the BEPS effort may generate tax reforms that improve the performance of income-based taxes as applied to the extractive sector (particularly limitations on interest deductions), it is unrealistic to expect the reforms to increase the yield from income-based taxes enough to provide governments with adequate compensation for the removal of their natural resources. In addition to pursuing BEPS reforms, developing countries should devote serious attention to expanding the use of fiscal instruments that do not depend on the measurement of net income but are based, instead, like royalties, on the value of product that is extracted.

There will be some adverse trade-offs involved in increasing reliance on royalties or other levies that are based on the gross value of product extracted. Economists are correct in their analysis that levies based on net income potentially do a better job of mitigating investor risks and therefore in encouraging investment. But the problem is that despite the theoretical advantages of taxes based on net income, they are so vulnerable administratively that continued heavy reliance on them can only lead to continued revenue shortfalls. It is true that royalties and similar methods are, like income-based taxes, vulnerable to some extent to the undervaluation of product - but as demonstrated above, the extent of the vulnerability is much less for royalties and similar levies than it is for income-based taxes. Moreover, royalties and other levies based on the value of extracted product have no vulnerability to profit shifting by excessive interest payments or payments to affiliates for intragroup services. Administratively, therefore, royalties and similar gross income levies are intrinsically much more robust than taxes based on net income.

Research is called for that moves beyond theoretical considerations and focuses empirically on the relative effectiveness of income-based taxes and gross income levies in actual practice. This research should employ data from actual cases and should compare the actual yields from particular levies with the amounts that the levies were originally estimated to generate. The literature is currently, to this author's knowledge, devoid of analyses other than broad anecdotal observations of the practical administrability of different kinds of natural resources levies. Critical research, based on hard data, is needed on this important question.

In addition, developing country governments, and the economists around the world who advise them, should give enhanced attention to the design of fiscal instruments that are based on gross product value but also incorporate some risk-mitigating features for investors, such as the graduation of royalty rates based on changes in product pricing and in

Not only taxes based on net income, but other arrangements that require the measurement of net income from a natural resource property, like production sharing arrangements, also can be vulnerable to misvaluation. 
the volume of production from a property. Relatively refined kinds of levies on gross product value are not unknown around the world today, but they should be given increased attention in economic research.

In sum, weighting natural resource levies toward taxes based on net income, while attractive in theory, is quite possibly quixotic in practice. The mix of fiscal instruments between levies based on net income and on the value of extracted product may well have shifted too far in the direction of income-based taxes. Reducing relative reliance on income-based taxes, despite the trade-offs involved in the sharing of investment risks, might assist governments materially in gaining more adequate compensation for the extraction of their natural resources. ${ }^{18}$

\subsection{Other industries}

In many developing countries, telecommunications companies (including mobile telephone and Internet providers), distributors of high-margin consumer products like branded foods and beverages, and banks and other financial institutions tend to have three traits in common. First, their services are central to the economies in which they conduct business. Second, the companies in these industries very often are local affiliates of foreign-owned multinational groups. And third, these companies tend to have very large opportunities to avoid corporate income taxation by shifting income to zero- and low-tax affiliates.

In particular, telecommunications companies are often heavily leveraged with related-party debt, facilitating income shifting through the payment of interest; and telecommunications companies typically have large networks of hard-to-value payments to and from affiliates, for such items as call origination and completion, roaming charges, and for technical services. Distributors of high-margin consumer products typically have substantial opportunity for profit shifting through royalties or other kinds of payments for the use of a group's trademarks, as well as through related-party borrowing. Banks and other financial companies, including insurance companies, typically have very large intragroup borrowings (and, in the case of insurance companies, reinsurance arrangements) that effectively render transfer pricing enforcement impossible even for the most experienced revenue administration.

With respect to all these industries, and perhaps others with similar characteristics, hardnosed research is called for to evaluate the extent to which actual revenue recoveries from corporate income tax have or have not conformed to expectations. Further, although governments should take advantage of anti-avoidance measures that arise from the BEPS process, including especially limitations on interest deductions, governments should be wary of placing excessive reliance on the prospect of substantially improved revenue recovery from these reforms. Revenue losses from profit shifting might be reduced somewhat as a result of BEPS reforms, but given the inexorable arithmetic of transfer pricing, under which even small misvaluations of related-party charges can lead to large revenue losses, corporate income tax is bound to remain disappointing as a source of revenues for developing countries. Again, this does not mean that developing countries should dispense with corporate income tax - but they should assign greater emphasis to alternative forms of taxations if they are to achieve greater revenue from these economically important but hardto-tax businesses.

To some extent increases in excise taxes, on products and services that tend to be supplied by multinational enterprises, might compensate for revenue that is now lost to corporate income tax avoidance. Excise taxes on telecommunications services, banking and insurance services, and some high-margin consumer products (notably alcoholic beverages and tobacco) are in use throughout the world, in countries at all levels of economic development.

18 See Clausing and Durst (forthcoming). 
By and large the administrative mechanisms for these taxes are already in place in developing countries. Greater reliance on excise taxes, therefore, generally would not require the forging of new ground in tax administration; the expansion would take the form of increasing rates and perhaps the coverage of existing taxes, rather than introducing new ones.

Of course, excise taxes have drawbacks, economically and politically. Both corporate income tax as imposed on the producers of goods and services, and excise taxes imposed on the purchase of goods and services, impose burdens on both consumers (in the form of higher after-tax prices) and producers (in the form of reduced demand for services and therefore lower after-tax profits). But in the case of excise taxes the mix of burdens probably falls, in most cases, more heavily on consumers, so excise taxes probably are more regressive in their incidence than corporate income tax. Further, regardless of the extent to which excise taxes are in fact regressive, they are highly visible to consumers and therefore undoubtedly are seen, domestically, as imposing greater consumer burdens than corporate income tax. In actuality, the regressive effects of excise taxes might be limited, especially if they are imposed on products other than basic necessities. Nevertheless, even excise taxes targeted at what might be seen as luxury goods and services will have some regressive effects, and the visibility of the tax is certain to fuel in political opposition. Moreover, because excise taxes impose burdens on multinational companies, through reductions in product demand, as well as on consumers, multinational companies can be expected to oppose increased excise taxes using arguments based on tax competition, just as companies have done with respect to corporate income taxation. Excise taxes therefore are far from an ideal tax, from either an economic or political perspective.

No tax, however, is ideal. All taxes impose burdens on some, all distort economic activity to some extent, all have built-in administrative limitations, and all face predictable sources of political opposition. And while excise taxes certainly can be regressive, the chronic inability of developing country governments to raise adequate revenue also imposes hardships on people with low incomes. Historically, I believe that developing countries have tended in their policy evaluations to under-appreciate the special vulnerability of income-based taxation to tax avoidance through misstated transfer prices of both income and expenses. The mix of fiscal instruments today may therefore be tipped excessively toward corporate income taxes, and insufficiently toward excise and similar taxes. Policymakers in developing countries, and the economists and others who advise them, should give renewed attention in research both to the intrinsic limitations of income-based taxation, and to the possibility of placing greater reliance on excise taxation for key industries.

Other areas of potential substantial revenue gain would not seek to reach the same base as corporate income tax, but nevertheless should be given serious attention by developing country policymakers. These include real property taxes and payroll taxes, the administrability of which probably is being continually enhanced by advances in the automation of property records and personnel compensation systems.

In addition, many developing countries should probably devote greater efforts to surmounting the perceived barriers to domestic revenue-raising that have led the perception that developing countries have no choice other than to rely on corporate income tax more heavily than other countries. Although it is true that the economies of many developing countries contain large sectors that are informal, in that they rely primarily on cash or barter payments rather than more easily traceable credit card payments or electronic fund transfers, not all the participants in countries' informal sectors are low-income individuals operating businesses at very low volume. Every developing country probably has businesses that are large and profitable, but nevertheless escape large amounts of tax through the prevalent use of cash payments. Intensive, targeted examinations of these businesses, perhaps employing technical assistance from countries with well-developed capacity for examining mid-sized 
businesses, might generate significant revenue sources while conveying a message to the public that tax laws are being enforced equitably. Developing countries, with the help of technical assistance that is available, should devote efforts to estimating the potential revenue yield from targeted examinations of large cash-based taxpayers, and should implement intensive examinations of those taxpayers with the largest apparent revenue potential. The inherent limitations of corporate income taxation in today's international context, which BEPS limitations are capable of addressing only to a limited extent, lend urgency to the need for developing countries to generate additional revenue from higherincome domestic taxpayers.

\section{Conclusion}

Given the imperfections that are to be found in all tax instruments, it is neither realistic nor wise for a country's policymakers to seek to design a theoretically perfect tax system. The best that can be achieved is a mix of tax instruments in which the desirable and undesirable qualities of each offset one another to some extent, so that the resulting system is capable of raising the revenue needed by a society with as little economic inefficiency and as little burden on poorer individuals as can reasonably be achieved. Trade-offs, and the use of overlapping fiscal instruments, are unavoidable in some situations.

It has been perceived for many years that corporate income tax should play an especially prominent role in the mix of fiscal instruments employed by developing countries. In recent years, however, it has been widely recognised that multinational groups, which comprise a large portion of corporate income tax base of developing countries, are systematically avoiding income taxation in all countries around the world through business structures built around base erosion and profit shifting. Moreover, an examination of the structure of income taxation reveals that magnified opportunities for avoidance are intrinsic to corporate income tax, and that even after the reforms that may arise from the OECD's BEPS process, large opportunities for tax avoidance by profit shifting are likely to remain.

It is important that developing countries do not permit the great attention that the international tax community has devoted to BEPS to raise unrealistic expectations concerning improvements that might be made to corporate income tax. Instead, the tax research and policy agendas should give very serious attention to alternative fiscal instruments, which may not encounter as insurmountable political barriers as those that appear to stand in the way of effective corporate income tax reform in the international setting. 


\section{References}

ActionAid (2012) Calling Time: Why SABMiller Should Stop Dodging Taxes in Africa (updated version, April2012), $<$ http://www.actionaid.org.uk/sites/default/files/doc_lib/calling_time_on_tax_avoidance. pdf>

Avi-Yonah, R. (2000) 'Globalization, Tax Competition, and the Fiscal Crisis of the Welfare State', Harvard Law Review 113:1573

_ (1997) The Rise and Fall of Arm's Length: A Study in the Evolution of U.S. International Taxation, (originally published 1995 in the Virginia Tax Review; updated version published as a University of Michigan Law School working paper in 1997 and available online at <law.bepress.com>

and Clausing, K. (2007) A Proposal to Adopt Formulary Apportionment for Corporate Income Taxation: The Hamilton Project, Brookings Institution

Bell, K. (2015) 'Officials at Paris Conference Hint At Major Changes to OECD Draft on Risk', 23 Transfer Pricing Report 1498

Christian Aid (2009) False Profits: Robbing the Poor to Keep the Rich Tax-Free, $<$ http://www.christianaid.org.uk/Images/false-profits.pdf>

Clausing, K. and Durst, M. (forthcoming) A Price-Based Royalty Tax?, ICTD working paper

Drucker, J. (2011) IRS Auditing How Google Shifted Profits, 31 October 2011, <http://www.bloomberg.com/news/articles/2011-10-13/irs-auditing-how-google-shiftedprofits-offshore-to-avoid-taxes>

Duhigg, C. and Kocieniewski, D. (2012) 'How Apple Sidesteps Billions in Taxes', The New York Times, 4/28/12, <http://www.nytimes.com/2012/04/29/business/apples-taxstrategy-aims-at-low-tax-states-and-nations.html?_r=1>

Durst, M. (2015) Limitations on Interest Deductions: A Suggested Perspective for Developing Countries, Working Paper No. 36, International Centre for Tax and Development

- (2014a) 'Self-Help and Altruism: Exploring the Problem of Tax Base Erosion in Developing Countries,' 23 Transfer Pricing Report 228

_ (2014b) 'Developing Country Taxation, Part III: Surmounting Transfer Pricing Problems of Distributors and Manufacturers', 23 Transfer Pricing Report 797 (2014)

_ Prospective Documentation in Transfer Pricing Today', Tax Law Review 57:37, 60-61

IMF (2014) Spillovers in International Corporate Taxation, IMF Policy Paper, 9 May 2014, Washington DC: International Monetary Fund, available at <http://www.imf.org/external/np/pp/eng/2014/050914.pdf>

(2012) Fiscal Regimes for Extractive Industries: Design and Implementation, available at <http://www.imf.org/external/np/pp/eng/2012/081512.pdf> 
Kleinbard, E. (2011a) 'Stateless Income’, 11 Florida Tax Review 699

_ (2011b) 'The Lessons of Stateless Income', 65 Tax Law Review 99

ICMM (2009) Minerals Taxation Regimes, International Council on Mining and Metals, available at <http://www.icmm.com/document/520>

Langbein, S. (1986) 'The Unitary Method and the Myth of Arm's Length', Tax Notes, 17 February 1986, at 625, 629-638

Mitchell, R. (2013) 'OECD Issues Revised Guidance on Transfer Pricing Safe Harbors', 22 Transfer Pricing Report 122, 5/30/13

OECD (2015) BEPS Action 3: Strengthening CFC Rules, Public Discussion Draft, May 12, 2015, Organisation for Economic Co-operation and Development

- (2014) A Report to G20 Development Working Group on the Impact of BEPS in Low Income Countries, Part 1 and Part 2, Organisation for Economic Co-operation and Development. Part 1 of the OECD report is available at <http://www.oecd.org/ctp/taxglobal/part-1-of-report-to-g20-dwg-on-the-impact-of-beps-in-low-income-countries.pdf>; Part 2 is available at <http://www.oecd.org/ctp/tax-global/part-2-of-report-to-g20-dwgon-the-impact-of-beps-in-low-income-countries.pdf>

Qassim, A. (2015) 'Large Companies, Not Governments, Drive Corporate Tax Policy, U.K. Attorney Says', Transfer Pricing Report, 30 June 2015 (quoting barrister Philip Baker)

Sunley, E., Baunsgaard, T. and Simard, D (2002) Revenue from the Oil and Gas Sector: Issues and Country Experience, IMF Post-Conference Draft June 8, 2002

US Congress (2010) Present Law and Background on Possible Income Shifting and Transfer Pricing, Staff of the Joint Committee on Taxation

Wells, B. and Lowell, C. (2012) 'Tax Base Erosion and Homeless Income: Collection at Source Is the Linchpin', 65 Tax Law Review 65:535 


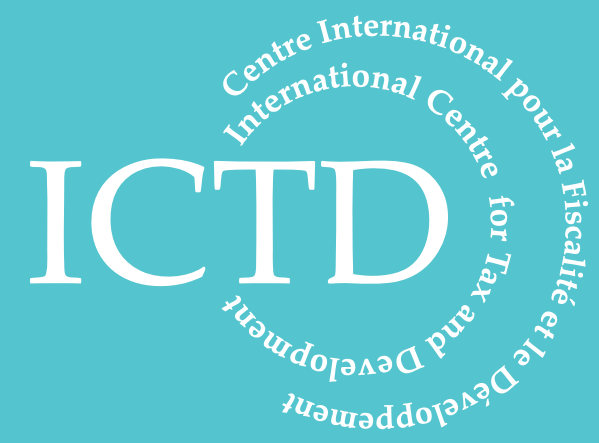

International Centre for Tax and Development at the Institute of Development Studies

Brighton BN1 9RE, UK

T: +44 (0) 1273606261

F: $+44(0) 1273621202$

E: info@ictd.ac

www.ictd.ac 